\title{
Household Consumption of Dairy Products - An Analysis of Consumer Behavior in Albania
}

\author{
PhD. Ilir Kapaj \\ Agriculture University of Tirana, Faculty of Economy and Agribusiness, Albania. \\ ikapaj@ubt.edu.al \\ Prof. As. Dr. Ana Mane Kapaj \\ Agriculture University of Tirana, Faculty of Economy and Agribusiness, Albania. \\ amane@ubt.edu.al
}

\section{Doi:10.5901/mjss.2013.v4n9p104}

\section{Abstract}

Household consumption of dairy products is one the major component in the total sales of the Albanian dairy industry. Therefore, understanding the factors which may significantly influence household consumption is important in the planning of farmers, processors and manufacturers. Consumers' responses to changes in price and non-price factors are basic to an economic analysis of almost all the policy decisions related to industry or government programs. Forecasting the future direction of household consumption, and how that direction might be modified through industry efforts or by national programs and policies, requires information on the relationships among prices, incomes, household characteristics and consumer demand. This study focuses on households as consuming units, explains and analyzes their purchasing behavior for dairy products. As milk is a very important component of the Albanians diet, this study explores consumer preferences for milk in Albania and also tries to determine consumers profiles based on their preferences and socio-demographic factors. To reach these objectives, this research designed a conjoint choice experiment survey and collected primary data in the most populated cities of Albania. This study provides useful information to different stakeholders including milk producers and importers. The milk industry and its marketers may benefit from this information by using it to strategically market their milk to different groups.

\section{Introduction}

Household consumption of dairy products is one the major component in the total sales of the Albanian dairy industry. Therefore, understanding the factors which may significantly influence household consumption is important in the planning of farmers, processors and manufacturers. Consumers' responses to changes in price and non-price factors are basic to an economic analysis of almost all the policy decisions related to industry or government programs. Forecasting the future direction of household consumption, and how that direction might be modified through industry efforts or by national programs and policies, requires information on the relationships among prices, incomes, household characteristics and consumer demand. This study focuses on households as consuming units, explains and analyzes their purchasing behavior for dairy products.

As milk is a very important component of the Albanians diet, this study explores consumer preferences for milk in Albania and also tries to determine consumers profiles based on their preferences and socio-demographic factors. To reach these objectives, this research collected primary data in the most populated cities of Albania, Tirana and Durres. A descriptive statistical analysis has been carried out to describe the dairy products in Albania and also a cross tabulation to look into the consumers groups. The study provides useful information to different stakeholders including milk producers and importers. The milk industry and its marketers may benefit from this information by using it to strategically market their milk to different groups.

\section{Milk production in Albania}

Livestock production is seen as a backbone of Albania's agriculture. The value of livestock production has increased from 63328 million leek in 2000, in 78438 million leek in 2010, which makes $57 \%$ of the total value of agricultural production of 138260 million leek (Statistical Yearbook 2011). Livestock products constitute a main source of food, and a high share of 
production still serves for subsistence purposes and as feeding for the calves.

Dairy activities have a long tradition in Albania due to the favorable natural resources for dairy production. In the plains, cattle production is dominant, while in the hills and mountains, sheep and goat production are more suitable. Traditional dairy products are yoghurt, butter, curd and different kinds of cheese from cow, sheep and goat milk. According the statistics of MAFCP total milk production has increased from 948000 ton in 2000, up to 1016000 ton in 2010 from which cow milk production was 868000 ton in 2010 (MAFCP statistical yearbook 2007). Some data of milk production through the years are given below in Figure 1.

Figure 1: Milk production through the years (000 ton)

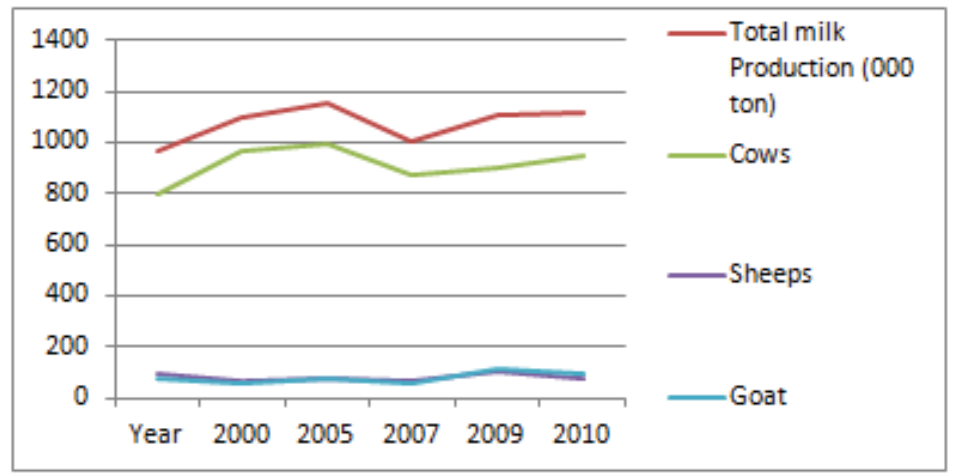

Source: Ministry of Agriculture, 2008

Milk production and collection system (mainly cow milk) in Albania is characterized by the existence of the informal (direct selling from farmers) and formal market channels (collection \& distribution by dairies). Milk production in Albania suffers still from problems of quality assurance. According the annual survey of the MAFCP in 2010 only $23 \%$ of produced milk is going to the dairies for processing, $45 \%$ of it is directly marketed, $19 \%$ it is used for self consuming and $13 \%$ is used for animal feeding (calves). A very big part of milk it is consumed directly and not processed and or controlled. The dairy sector is one of the most important industries in the agro-business sector. It provides $90 \%$ of the milk supply for Albanian consumers. This sector has been very significantly growing during the last five years. If we see at some statistical data of the investments done in these industry there has been a significant increase in the years 2005 and 2006, Figure 2.

Figure 2: Investments in the milk industry through the years (million ALL)

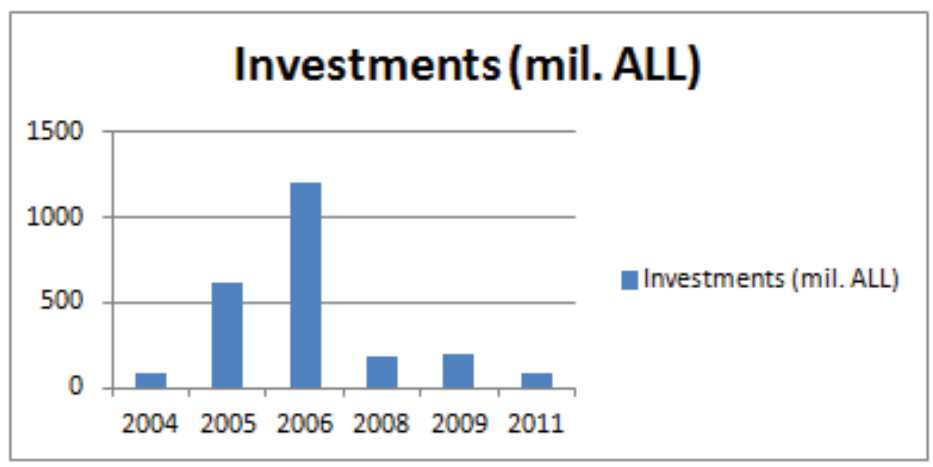

Source: Ministry of Agriculture, 2012

However, the industry remains relatively immature; although the raw milk production increased at a rate of 15\% (MAFCP- 
statistical yearbook 2010) over the last five years. The production of high quality milk is the key to establish a profitable future for the dairy industry. The dairy sector is often exposed to risks linked to the raw material supply because there is not in place a vertically integrated system, concerning the raw material supply and the distribution of the products to the final consumer. In the dairy industry milk remains the most important component in terms of production and also in consumption. If we look at the share that milk has in the dairy industry it is significant higher compared with other products like cheese, butter and yogurt, Figure 3.

Figure 3: Share of dairy agro-industry production in 2011 (ton)

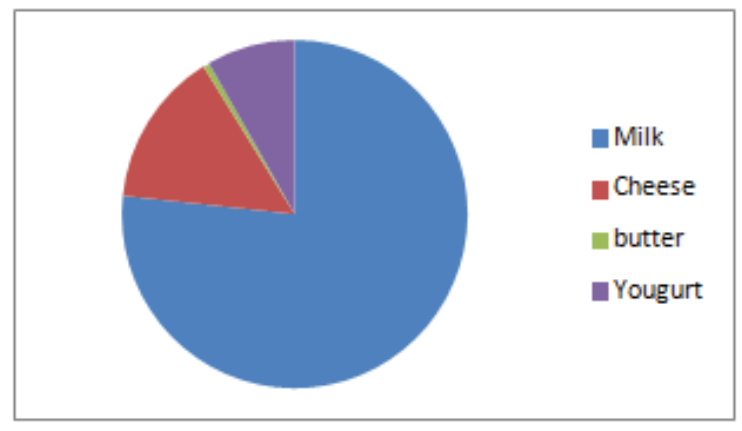

Source: Ministry of Agriculture, 2012

\section{Results and Conclusions}

From the data collected in 186 househols in Tirana and Durres city it can be said that milk consumption is a very important component in the Albanian daily diet. Only $4.7 \%$ of the households haven't consumed milk recently, whereas the rest of them stated that they consume milk 2-3 kg a week. 87 (46.5\%) of the households listed "helth benefits" reason as the most important one for their every day milk consumption. Regarding the children influence in the household consumption we have got the following answers. As it can be seen from the figure below the majority of the households are very highly afected from the children presence in their milk consumption.

Figure 4: Children influence in Milk consumption

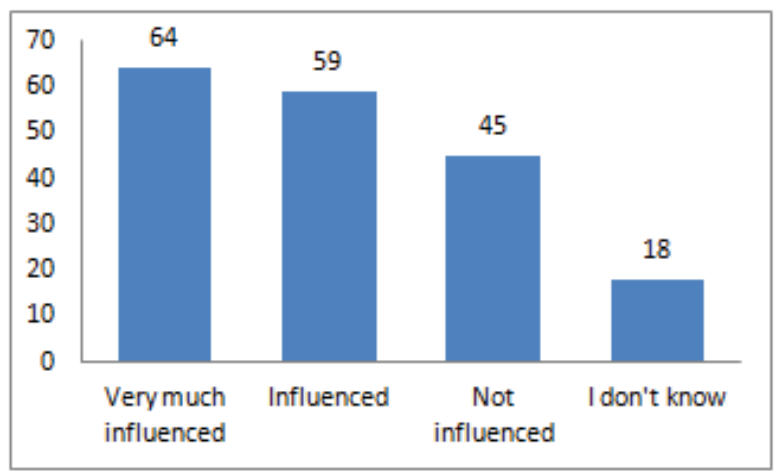

In this stydy we have also investigated how do the household react towards the places where to buy milk. The households involved we ansewred almost equally regarding the place of purchase. They are divided among the three possibilities, if they buy the product in "Supermarket", "Small naughbourhood shop" or "At home", equally. 
Figure 5: Purchase place of milk

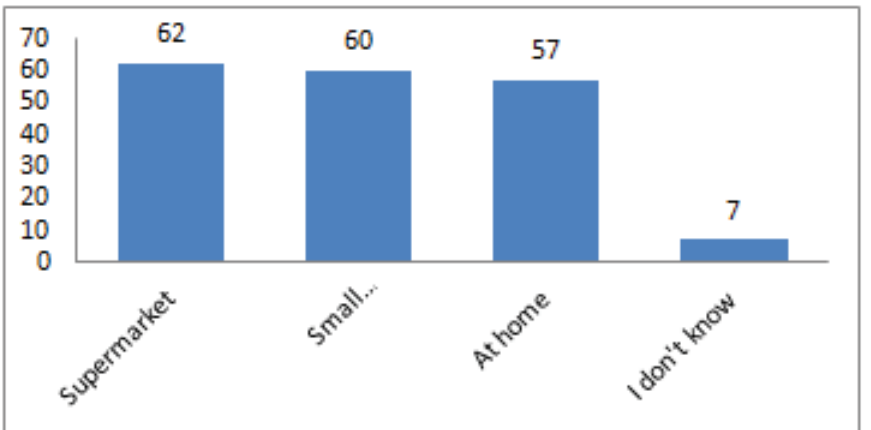

Milk type and the consumer reactipon towards it has been another important point of the research. Acording the their answers the majority of the households prefer "Fresh pasteurized milk).

Figure 6: Consumer preferences towards milk type

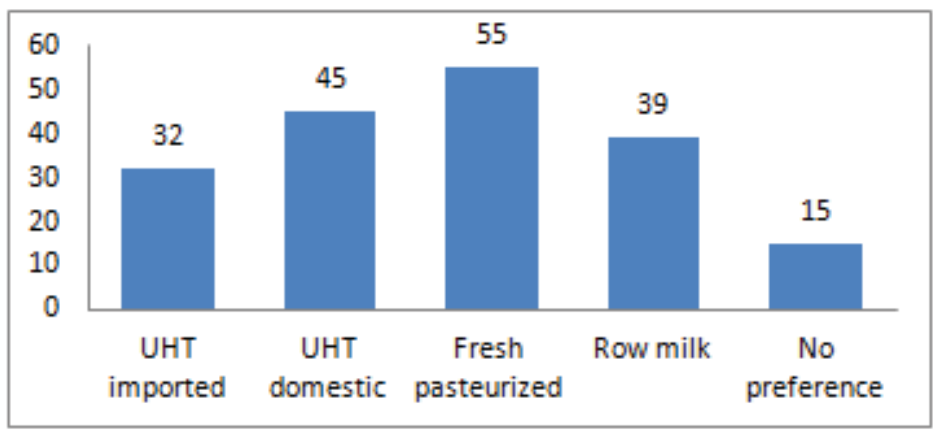

During this study was also thought that presented an interest to see how they the household are distributed among the two variables included in the study, type of milk and income. For this reason we have done a cross tabulation as below:

Table 1: Consumers distribution acording to milk type and household income (€/month)

\begin{tabular}{||c||c||c||c||c||c||c||}
\hline \multicolumn{1}{||c||}{} & \multicolumn{5}{c|}{ Type of Milk } \\
\hline \hline $\begin{array}{c}\text { Consumers } \\
\text { income }\end{array}$ & $\begin{array}{c}\text { UHT } \\
\text { imported }\end{array}$ & $\begin{array}{c}\text { UHT } \\
\text { domestic }\end{array}$ & $\begin{array}{c}\text { Fresh } \\
\text { pasteurized }\end{array}$ & $\begin{array}{c}\text { Row } \\
\text { milk }\end{array}$ & $\begin{array}{c}\text { No } \\
\text { preference }\end{array}$ & Total \\
\hline \hline$-400 €$ & 6 & 10 & 5 & 9 & 4 & 34 \\
\hline \hline $400 €-800 €$ & 17 & 19 & 24 & 22 & 4 & 86 \\
\hline \hline $800 €-1300 €$ & 6 & 12 & 22 & 6 & 6 & 52 \\
\hline \hline Over 1300€ & 3 & 4 & 4 & 2 & 1 & 14 \\
\hline \hline Total & 32 & 45 & 55 & 39 & 15 & 186 \\
\hline \hline
\end{tabular}

This is done keeping in mind the purpose of the study to identify groups of consumers with special features that prefer a certain type of milk. If we take a look at the observed cross distribution of the households, most common groups of customers focus on consumption of fresh pasteurized milk and that row combined with a level of more than towards the highest income. 


\section{Conclusion}

Our study focuses on consumers' preferences for milk in Albania. The idea that motivated this research is that before any course of action supporting the domestic milk production industry can be undertaken, we need to know what consumers want. Milk producers must meet consumers' demand for milk when there is demand in order to remain competitive. Once we are able to clearly describe the existing demand for milk, a marketing strategy can be properly developed.

This study makes it possible to identify four milk consumers groups according to their preferences on the product attributes. All these groups represent different potential market segments with specific characteristics. The most populated consumers groups preferred fresh pasteurized milk and this is most common in the middle income groups. Also interesting is the high percentage of the row milk consumption, but in the case of Albania quality and safety of the dairy products especially milk is not very much reflected in the consumer behavior.

\section{References}

Campbell, B.L., R.G. Nelson, R.C. Ebel, W.A. Dozier, J.L. Adrian, and B.R. Hockema. 2004. "Fruit Quality Characteristics That Affect Consumer Preferences for Satsuma Mandarins." HortScience 39(7): 1664-1669.

Green, P.E., V. Srinivasan. 1978. "Conjoint Analysis in Consumer Research: Issues and Outlook." Journal of Consumer Research 5(2): 103-121.

1990. "Conjoint Analysis in Marketing: New Developments with Implications for Research and Practice." Journal of Marketing 54(4): 3-20.

Green, P.E., A.M. Krieger, and Y. Wind. 2001. "Thirty Years of Conjoint Analysis: Reflections and Prospects." Interfaces 31(3): S56-S73.

Hair, J.F. Jr., R.E. Anderson, R.L. Tatham, and W.C. Black. 1998. Multivariate Data Analysis, 5th ed. Upper Saddle River NJ: Prentice Hall

Halbrendt, C.K., F.F. Wirth, and G.F. Vaughn. 1991. "Conjoint Analysis of the Mid-Atlantic Food-Fish Market for Farm-Raised Hybrid Striped Bass." Southern Journal of Agricultural Economics 23(1): 155-163.

Halbrendt, 2010." Consumer Preference for Olive Oil: The Case of Tirana, Albania". IFAMA Journal, Volume 13, Issue 3.

Ministry of Agriculture Food \& Consumer Protection. 2007. Rural Development Strategy. Tirana Albania 2012. Annual Report. Tirana Albania

Petrick.M, Schreiber.C,.and Weingarten.P. 2003. Competitiveness of milk and wine production and processing in Albania, IAMA Forum, October. 